\title{
TRACHEAL EPITHELIUM OF RABBITS AFTER REPEATED INHALATIONS OF MINERAL WATER AEROSOL
}

\author{
V. KONRÁDOVÁ ${ }^{1}$, L. VAJNER ${ }^{1}$, J. UHLÍK $^{1}$, J. ZOCOVÁ ${ }^{2}$ \\ ${ }^{1}$ Institute of Histology and Embryology, $2^{\text {nd }}$ Medical Faculty \\ ${ }^{2}$ Department of Applied Mathematics and Computer Science, Faculty of Science \\ Charles University, Prague, Czech Republic
}

Received May 30, 2001

Accepted October 31, 2001

Abstract

Konrádová V., L. Vajner, J. Uhlík, J. Zocová: Tracheal Epithelium of Rabbits after Repeated Inhalations of Mineral Water Aerosol. Acta Vet. Brno 2001, 70: 391-396.

In experiment, the effect of repeated inhalations of mineral water aerosol on the airway epithelium was investigated. Six rabbits inhaled mineral water for $10 \mathrm{~min} 5 \times$ in the course of 5 days, seven animals served as untreated controls. The tracheal mucous membrane was processed using standard methods of transmission electron microscopy; the results were evaluated quantitatively. In paraffin-embedded material, the methods of conventional and lectin histochemistry were employed. Due to the contact with mineral water aerosol, the goblet cells were overstimulated and the mechanism of secretion was accelerated. The exhausted goblet cells represented $66 \pm 2 \%$. High level of goblet cells' stimulation resulted in changes in their distribution in the epithelium. Small intraepithelial mucous glands were formed by $33 \pm 4 \%$ of goblet cells. Goblet cells containing neutral glycoconjugates disappeared. A significant $(\alpha=0.01)$ increase in number of cells producing acid sulphated glycoconjugates was accompanied with significant $(\alpha=0.01)$ decrease in cells containing $\alpha(2-3)$ sialylated ones. In the ciliated cells, slight apical blebbing and mild signs of pathological alteration of the deeper portions of their cytoplasm were noticed. In the ciliary border, the mean number of cilia was $7.2 \pm 0.3 / \mathrm{m}^{2}$. The altered kinocilia represented $5.8 \pm 1.4 \%$. These values were slightly but significantly $(\alpha=0.01)$ lower compared with controls. As morphological signs of impaired self-cleaning ability of the airway epithelium, clumps of condensed mucus were discovered in the area of the slightly impaired ciliary border. According to our classification of the airway epithelium injury, the degree of damage to the tracheal epithelium was mild to moderate.

Airways, ultrastructure, lectin histochemistry, glycoconjugates, ciliated cells, goblet cells

In our preceding study, we demonstrated the effect of a single 10-min inhalation of mineral water on the airways. In the tracheal epithelium, the secretory elements were overstimulated and changes in the character of their glycoconjugates (GCs) were recorded (Konrádová et al. 2001). In clinical practice, whole series of inhalations are usually prescribed. Therefore, we decided to investigate also the effect of repeated inhalations of mineral water aerosol on the airway epithelium.

\section{Materials and Methods}

In our experiments, 13 SPF New Zealand White male rabbits (Charles River Deutschland, Sulzfeld, Germany) of body weight 1,500 - 3,000 g, 3-7 months of age were used. The animals were kept in our breeding facility under standard conditions, fed with complete granulated mixture TM-MaK 1. Seven animals served as untreated controls. For administration of mineral water aerosol, a plastic cage connected with the inhalation device PARI Master and nebuliser PARI LL (Pari GmbH, Starnberg, Germany, medium diameter of produced droplets $3.1 \mu \mathrm{m}$, total output 0.6 $\mathrm{g} / \mathrm{min}$ ) was used. The rabbits inhaled an aerosol of natural hypertonic iodinated spring water (osmolarity $331 \mathrm{mOsm}$, $\mathrm{pH}$ 6.48) for $10 \mathrm{~min} 5 \times$ in the course of 5 days. Chemical composition of used spring water is given in Tab. 1 . Under general anaesthesia, using the i.m. administration of a mixture of ketamine and xylazine according to the certification of the Animals Protection Expert Commission of the Faculty, the material for electron microscopic and histochemical examinations was collected $24 \mathrm{~h}$ after the last exposure. Tiny fragments of the tracheal mucous membrane were

Address for correspondence:

Prof. MUDr. V. Konrádová. DrSc.

Institute of Histology and Embryology

V Úvalu 84, 15006 Prague 5, Czech Republic
Phone: +420224435980

Fax: +4202 24435820

ova@lfmotol.cuni.cz

http://www vfu.cz/acta-vet/actavet.htm 
Table 1

Chemical composition of the inhaled mineral water

\begin{tabular}{|c|c|c|c|c|c|c|c|}
\hline & $\mathrm{Mg} / \mathrm{l}$ & & $\mathrm{mg} / \mathrm{l}$ & & $\mathrm{mg} / \mathrm{l}$ & & $\mathrm{mg} / \mathrm{l}$ \\
\hline $\mathrm{Li}^{+}$ & 13.48 & $\mathrm{Zn}^{2+}$ & 0.0023 & $\mathrm{Fe}^{\mathrm{II}}$ & 3.810 & $\mathrm{NO}_{2}^{-}$ & 0.00 \\
\hline $\mathrm{Na}^{+}$ & 3292.0 & $\mathrm{Cd}^{2+}$ & 0.000003 & $\mathrm{Co}^{2+}$ & 0.0003 & $\mathrm{NO}_{3}^{-}$ & 0.00 \\
\hline $\mathrm{K}^{+}$ & 160.5 & $\mathrm{Hg}$ & $<0.0001$ & $\mathrm{Ni}^{2+}$ & 0.0001 & $\mathrm{HPO}_{4}{ }^{2-}$ & 0.039 \\
\hline $\mathrm{NH}_{4}^{+}$ & 13.16 & $\mathrm{Al}$ & 0.359 & $\mathrm{U}^{\mathrm{III}}$ & $<0.0005$ & $\mathrm{HAsO}_{4}{ }^{2-}$ & 0.003 \\
\hline $\mathrm{Cu}^{2+}$ & 0.0316 & $\mathrm{~Pb}^{2+}$ & 0.00008 & $\mathrm{~F}^{-}$ & 2.932 & $\mathrm{HCO}_{3}^{-}$ & 6010.0 \\
\hline $\mathrm{Be}^{2+}$ & 0.00157 & $\mathrm{~V}^{\mathrm{IV}}$ & 0.00370 & $\mathrm{Cl}^{-}$ & 2319.0 & $\mathrm{HBO}_{2}$ & 413.0 \\
\hline $\mathrm{Mg}^{2+}$ & 15.07 & $\mathrm{Cr}$ & 0.0016 & $\mathrm{Br}^{-}$ & 9.068 & $\mathrm{H}_{2} \mathrm{SiO}_{3}$ & 1.19 \\
\hline $\mathrm{Ca}^{2+}$ & 258.5 & $\mathrm{Mo}^{\mathrm{VI}}$ & 0.0001 & $\mathrm{I}^{-}$ & 8.993 & $\mathrm{CO}_{2}$ & 1984.0 \\
\hline $\mathrm{Sr}^{2+}$ & 5.245 & $\mathrm{UO}_{2}{ }^{2+}$ & $<0.0005$ & $\mathrm{HS}^{-}$ & 0.00 & & \\
\hline $\mathrm{Ba}^{2+}$ & 11.02 & $\mathrm{Mn}^{2+}$ & 0.458 & $\mathrm{SO}_{4}^{2-}$ & 0.50 & & \\
\hline
\end{tabular}

processed using standard methods of transmission electron microscopy (Konrádová 1991). The ciliary border and the functional state of the goblet cells were evaluated quantitatively. To evaluate the distribution of goblet cells in the epithelium, the isolated elements and the goblet cells arranged in groups were distinguished. The secretory elements were further classified into three categories: 1) mucus-filled, 2) mucus-discharging, 3) degenerated ones. Four categories of kinocilia were distinguished: 1) intact $9+2$ cilia, 2) slightly damaged pathological cilia with loca swellings of the ciliary membrane or with tiny vacuoles situated in their shafts, 3 ) degenerating cilia, represented by axonemes incorporated into cytoplasmic blebs or by isolated axonemes, 4) malformed cilia with either abnormal arrangement or number of microtubules in their axonemes.

In the paraffin-embedded material, the methods of conventional histochemistry (Alcian Blue /AB/pH 2.5 - PAS and $\mathrm{AB} \mathrm{pH} 1.0$ ) as well as of in situ lectin histochemistry were employed (V ajner et al. 2000). Maackia amurensis agglutinin /MAA/ (Boehringer, Mannheim, Germany), Sambucus nigra agglutinin /SNA/ (Boehringer, Mannheim, Germany), and Tritrichomonas mobilensis lectin/TML/ (Calbiochem, La Jolla, USA) were used. Combination of these histochemical methods recognises neutral, acid sulphated and acid sialylated $[\alpha(2-3), \alpha(2-6)$ and total] GCs in the goblet cells' secretion.

In controls and after repeated inhalations of mineral water, $1,058 \mu \mathrm{m}^{2}$ and $1,673 \mu \mathrm{m}^{2}$ of ciliary border with 10,252 and 12,007 kinocilia were evaluated, respectively. In those experimental groups also a total of 186 and 475 goblet cells using electron microscopy and 398 and 387 goblet cells in histochemical studies were studied, respectively. For statistical evaluation of the ultrastructural findings, relative values of individual categories of goblet cells and of cilia were evaluated by the chi-square test of homogeneity in frequency tables. To specify categories causing deviations from the hypothesis of homogeneity, adjusted standardised deviations were used. In histochemical studies, relative values of six categories of goblet cells, revealed by individual methods, were evaluated in similar manner described above. The Yates' correction in low frequencies was used when appropriate. The equivalency of the sialylated glycoconjugate detecting methods was tested by the paired $t$-test, median (sign) test and Wilcoxon's paired test. Means of cilia/ $\mu \mathrm{m}^{2}$ were compared by one-way analysis of variance (ANOVA). The differences between groups were assessed by Tukey's test or Bonferroni's method for multiple comparison. The Levene's test for equal variances was also performed. As a non-parametric analogy of the ANOVA, Kruskal-Wallis test was used.

\section{Results}

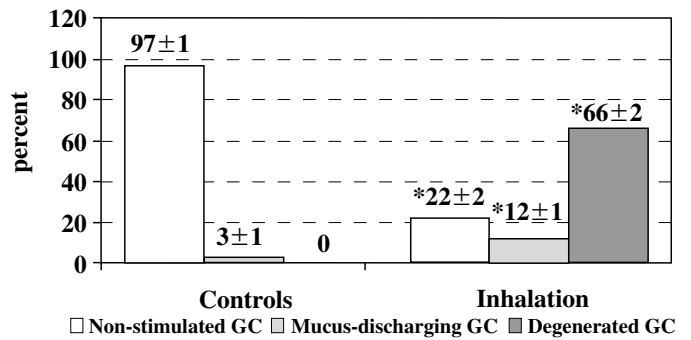

Fig. 1. $\mathrm{N}=3$, values are expresed as mean $\pm \mathrm{SD}$, values marked* significantly differ $(\alpha=0.01)$ from control values

Tracheal epithelium of control rabbits

In control rabbits, the tracheae were lined with a pseudostratified columnar ciliated epithelium composed of ciliated, goblet, basal cells and a few differentiating elements. Goblet cells were mostly filled with mucus (Fig. 1). They were scattered among the ciliated ones. Only $6 \pm 3 \%$ of them were arranged in tiny groups, $3 \pm 1 \%$ of 
secretory elements discharged their secretion mostly by means of gradual evacuation of the individual apical mucous granules. The conventional histochemistry revealed the dominance of goblet cells containing acid GCs. The proportion of goblet cells containing sulphated GCs, detected by conventional histochemistry, and the total percentage of goblet cells containing sialylated GCs visualised by the reactions with lectins were given in Table 2. The proportions of cells containing total sialylated GCs

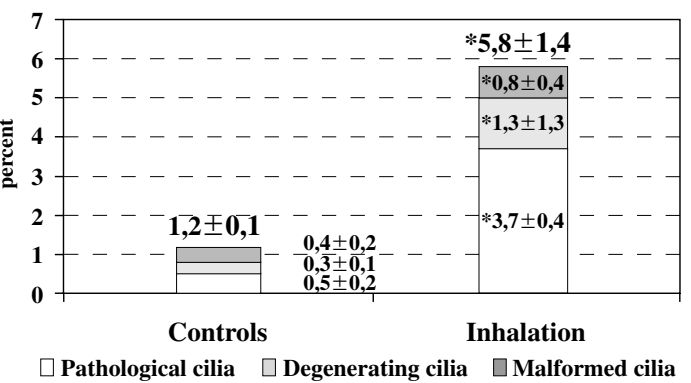

Fig. 2. $\mathrm{N}=3$, values are expresed as mean $\pm \mathrm{SD}$, values marked* significantly differ $(\alpha=0.01)$ from control values revealed by two methods of lectin histochemistry did not differ significantly. In the regular ciliary border, $9.7 \pm 0.3$ cilia per $1 \mu \mathrm{m}^{2}$ were found, $98.8 \pm 0.1 \%$ of them were intact. The proportions of pathological, degenerating and malformed cilia were given in Fig. 2.

Table 2

Quantitative evaluation of goblet cells containing glycoconjugates (GCs) of given chemical composition in the tracheal epithelium of rabbits after repeated inhalations of mineral water aerosol (relative values)

\begin{tabular}{|c|c|c|}
\hline & Controls & Inhalation \\
\hline Total acid GCs (AB pH 2.5 - PAS) & $98.5 \pm 2.4 \%$ & $\# 100.0 \pm 0.0 \%$ \\
\hline Neutral GCs (AB pH 2.5 - PAS) & $1.5 \pm 2.4 \%$ & $\# 0.0 \pm 0.0 \%$ \\
\hline Acid sulphated GCs (AB pH1) & $71.9 \pm 6.4 \%$ & $* 91.0 \pm 16.8 \%$ \\
\hline (2-3) sialylated GCs (MAA) & $27.9 \pm 8.4 \%$ & $* 9.3 \pm 12.0 \%$ \\
\hline (2-6) sialylated GCs (SNA) & $2.3 \pm 2.9 \%$ & $1.3 \pm 7.7 \%$ \\
\hline Total sialylated GCs (MAA + SNA) & $30.2 \pm 9.6 \%$ & $* 10.6 \pm 17.0 \%$ \\
\hline Total sialylated GCs (TML) & $26.6 \pm 11.5 \%$ & $* 9.3 \pm 21.7 \%$ \\
\hline
\end{tabular}

Values are expressed as mean $\mathrm{SD}$, values designated $*$ differ significantly $(\alpha=0.01)$ from controls, values designated \# differ significantly $(\alpha=0.05)$ from controls. $\mathrm{AB}-$ Alcian Blue

MAA - Maackia amurensis agglutinin

SNA - Sambucus nigra agglutinin

TML - Tritrichomonas mobilensis lectin

Tracheal epithelium of rabbits after repeated inhalations of mineral water aerosol

Tracheae of rabbits exposed to repeated inhalations of mineral water aerosol were lined with an altered pseudostratified ciliated epithelium with narrow intercellular spaces and intact apical junctional complexes (Plate III, Fig. 3).

In the epithelium, $33 \pm 4 \%$ of goblet cells were arranged in groups forming thus small intraepithelial mucous glands. Signs of mucus evacuation were not revealed in $22 \pm 2 \%$ of them. They were mostly filled with large light mucous granules. Only a few cells containing in their cytoplasm isolated small mucous granules were noticed. Goblet cells discharging their secretion represented $12 \pm 1 \%$ of secretory elements (Fig. 1). Evacuation of apical mucous granules and detachment of whole packets of granules were often encountered (Plate III, Fig. 4). The exhausted goblet cells prevailed in the epithelium. They represented $66 \pm 2 \%$ of secretory elements (Fig. 1). Their cytoplasm was mostly highly electron dense and remnants of their degenerated cytoplasm were often observed above the epithelium in the area of the ciliary border (Plate III, Figs. 5, 6). 
After repeated inhalations of mineral water, the goblet cells containing neutral GCs disappeared completely, the cells producing acid sulphated GCs, prevailed in the epithelium. The total percentage of cells containing acid sialylated GCs oscillated between $9.3 \%$ and $10.6 \%$ according to used methods of lectin histochemistry (Table 2). The proportions of cells containing $\alpha(2-3)$ and $\alpha(2-6)$ sialylated GCs are presented in Table 2.

The ciliated cells were less damaged compared to the secretory ones. On their apical portions, only isolated small cytoplasmic blebs were developed. Inside those cytoplasmic protrusions, a few axonemes of kinocilia were encountered (Plate IV, Fig. 7). In the deeper portions of ciliated cells' cytoplasm, a slight increase in the number of small vacuoles, secondary lysosomes, dilatation of the cisternae of granular endoplasmic reticulum and Golgi complex and altered mitochondria were observed (Plate IV, Figs 3, 8).

The regular arrangement of the ciliary border was slightly impaired. The mean number of cilia was $7.2 \pm 0.3 / \mu \mathrm{m}^{2}$. The altered elements represented $5.8 \pm 1.4 \%$ (Plate IV, Figs 7, 9). The proportions of the individual types of altered cilia were given in Fig. 2. In some places among the kinocilia, clumps of inspissated mucus were noticed (Plate IV, Fig. 10).

\section{Discussion}

In our previous study (Konrádová et al. 2001), we demonstrated that the target cells for the function of mineral water aerosol were the secretory elements in the airway epithelium. Also after repeated inhalations of mineral water, the goblet cells were overstimulated and their mechanism of mucus evacuation was accelerated. Signs of both merocrine and apocrine types of secretion were observed. In agreement with our previous study (Konrádová et al. 2001), compound exocytosis (Specian and Neutra 1980; Roumagnac and Laboisse 1987; Specian and Oliver 1991; Konrádová et al. 1996; New man et al. 1996) was not encountered $24 \mathrm{~h}$ after last aerosol administration.

After single administration of mineral water aerosol, the goblet cells discharged their mucus and then they mostly took part in further secretory cycles. Only a few exhausted secretory cells degenerated. Cells not entirely filled with secretory granules prevailed in the epithelium (Konrádová et al. 2001). Repeated inhalations of mineral water were responsible for more serious damage of the secretory elements. Most goblet cells were exhausted; they usually degenerated and were gradually sloughed off. Only isolated "small mucous granules cells" (Becci et al. 1978) representing the differentiating secretory cells were discovered in the epithelium.

High level of secretory cells' stimulation resulted in marked changes in distribution of goblet cells in the epithelium (Becci et al. 1978; Konrádová et al. 1990, 1996). In controls, less than $10 \%$ of secretory elements formed small groups, while about one third of them participated in the formation of intraepithelial mucous glands after repeated inhalations of mineral water.

Single inhalation of mineral water aerosol induced only slight changes in the composition of GCs in the secretion of goblet cells (Konrádová et al. 2001). As one of the first signs of goblet cells overstimulation, the $\alpha(2-6)$ sialylated GCs disappeared completely from the epithelium (Vajner 1998; Konrádová et al. 2000; Vajner et al. 2000). After repeated inhalations of mineral water, high level of goblet cells injury resulted in total disappearance of neutral GCs, predominance of acid sulphated GCs and significant $(\alpha=0.01)$ decrease especially in $\alpha(2-3)$ sialylated ones in their secretion. In accordance with other authors (Lamb and Reid 1972; Jones and Reid 1978; Damjanov 1987; Jeffery et al. 1992), we often demonstrated similar changes in the composition of the GCs in severely damaged airway epithelium (Vajner et al. 2000, 2001a,b).

Due to repeated inhalations of mineral water aerosol, the ciliated cells were less damaged compared to the goblet ones. Slight apical blebbing accompanied with destruction of a few 
kinocilia and only mild signs of pathological alteration of deeper portions of the cytoplasm of ciliated cells were noticed.

The ciliary border was also impaired. Slight, but significant $(\alpha=0.01)$ decrease in the mean number of kinocilia/ $\mu \mathrm{m}^{2}$, was accompanied by significant $(\alpha=0.01)$ increase in percentage of altered cilia. The greatest increase in number was ascertained in the slightly damaged pathological cilia.

In the area of the slightly impaired ciliary border, clumps of condensed mucus were discovered after repeated inhalations of mineral water. In agreement with our previous studies (Konrádová 1991) and also with other authors who have studied the effects of mucus flow impairment in airways (Stratmann et al. 1991; Wanner et al. 1996; Geis er et al. 1997), we regarded the appearance of inspissated secretion embedding free kinocilia as a morphological sign of impaired self-cleaning ability of the airway epithelium.

Based on our previous studies, classification of the airway epithelium injury was proposed (Konrádová 1991). We took into consideration the percentage of stimulated goblet cells, the degree of acceleration of mechanism of their secretion, the average number of kinocilia/ $\mu \mathrm{m}^{2}$, the percentage of altered kinocilia and the appearance of the morphological signs of the impairment of the self-cleaning ability of the airway epithelium. According to this classification, the degree of damage to the tracheal epithelium was mild to moderate due to the repeated inhalations of mineral water (Table 3), but high level of secretory cells' stimulation resulted in goblet cells hyperplasia with the formation of intraepithelial mucous glands.

Table 3

Evaluation of the degree of damage to the airway epithelium of rabbits after repeated inhalation of mineral water

\begin{tabular}{|c|c|c|c|c|c|c|}
\hline & \multirow{2}{*}{$\begin{array}{l}\text { Control } \\
\text { rabbits }\end{array}$} & \multicolumn{3}{|c|}{ Degree of damage } & \multirow{2}{*}{ Inhalation } \\
\hline & & & mild & moderate & severe & \\
\hline Stimu & ted GC & $<3 \%$ & $3-50 \%$ & $50-90 \%$ & $>90 \%$ & $78 \%$ \\
\hline \multirow{3}{*}{ Ratio } & Discharging GC & degenerated & \multirow{3}{*}{$>1$} & \multirow{3}{*}{$0.1-1$} & \multirow{3}{*}{$<0.1$} & \multirow{3}{*}{0.18} \\
\hline & & GC & & & & \\
\hline & Degenerated GC & not found & & & & \\
\hline \multicolumn{2}{|c|}{ Number of cilia / $\mu \mathrm{m}^{2}$} & $>9$ & $7-9$ & $3-7$ & $<3$ & 7.2 \\
\hline \multicolumn{2}{|c|}{ Altered cilia } & $<1.2 \%$ & $1.2-2.0 \%$ & $2.0-10.0 \%$ & $>10.0 \%$ & $5.8 \%$ \\
\hline \multicolumn{2}{|c|}{$\begin{array}{l}\text { Signs of impairment of } \\
\text { the self-cleaning ability }\end{array}$} & 0 & \pm & + & ++ & \pm \\
\hline
\end{tabular}

$\mathrm{GC}=$ goblet cells

In clinical practice, repeated inhalations of various aerosols represent constituent parts of therapeutic procedures in patients with chronic or repeated respiratory disorders. The aim of our study was to demonstrate the adverse effect of those procedures on the airway epithelium.

\section{Epitel trachey králíků po opakovaných inhalacích aerosolu minerální vody}

V experimentu autoři studovali účinek opakovaných inhalací aerosolu minerální vody na epitel dýchacích cest. Šest králíků inhalovalo minerální vodu 10 minut celkem $5 \times$ v průběhu 5 dnů, sedm králíků sloužilo jako kontroly. Vzorky tracheální sliznice byly vyšetřeny pomocí transmisní elektronové mikroskopie, výsledky byly hodnoceny kvantitativně. Pro určení charakteru produkovaných glykokonjugátů byly užity metody konvenční a lektinové histochemie. Působením aerosolu minerální vody byly pohárkové buňky nadměrně stimulovány a mechanismus jejich sekrece byl urychlen. Zcela vyprázdněné pohárkové buňky představovaly $66 \pm 2 \%$ buněk. Vysoký stupeň stimulace pohárkových buněk způsobil změnu 
v jejich distribuci v epitelu, $33 \pm 4 \%$ pohárkových buněk tvořilo drobné intraepitelové hlenové žlázky. Pohárkové buňky obsahující neutrální glykokonjugáty zcela vymizely. Statisticky významný $(\alpha=0,01)$ vzestup počtu pohárkových buněk produkujících kyselé sulfonované glykokonjugáty byl provázen statisticky významným $(\alpha=0,01)$ poklesem počtu buněk obsahujících $\alpha(2-3)$ sialované glykokonjugáty. Na řasinkových buňkách jsme pozorovali tvorbu nepř́liš četných drobných apikálních cytoplazmatických protruzí a mírnou patologickou alteraci hlubších partií cytoplazmy. Počet kinocilií průměrně se vyskytujících na $\mu \mathrm{m}^{2}$ řasinkového lemu poklesl na 7,2 $\pm 0,3$. Počet alterovaných kinocilií dosáhl 5,8 $\pm 1,4 \%$. Obě hodnoty se statisticky významně $(\alpha=0,01)$ liší od nálezů u kontrol. Jako morfologickou známku narušení samočisticí schopnosti epitelu jsme v oblasti lehce narušeného řasinkového lemu nalezli shluky kondenzovaného sekretu. Podle naší klasifikace je poškození epitelu trachey způsobené opakovanou inhalací aerosolu minerální vody lehké až stř̌edně těžké.

\section{Acknowledgements}

This work was supported by the grant No. 185/98 of Charles University Grant Agency and by the research project No. 111300003 of Ministry of Education of the Czech Republic.

\section{References}

BECCI, P., McDOWELL, E. M., TRUMP, B. F. 1978: The respiratory epithelium II. J. Natl. Cancer Inst. 61: 551561

DAMJANOV, I. 1987: Biology of disease. Lectin cytochemistry and histochemistry. Lab. Invest. 57: 5-20

GEISER, M., IMHOF, V., SIEGENTHALER, W., GRUNDER, R., GEHR, P. 1997: Ultrastructure of the aqueous lining layer in hamster airways. Microsc. Res. Tech. 36: 428-437

JEFFERY, P. K., GAILLARD, D., MORET, S. 1992: Human airway secretory cells during development and in mature airway epithelium. Eur. Respir. J. 5: 93-104

JONES, R., REID, L. 1978: Secretory cells and their glycoproteins in health and disease. Brit. Med. Bull. 34: 9-16

KONRÁDOVÁ, V. 1991: Quantitative evaluation of the degree of damage to tracheal epithelium. Func. Develop. Morphol. 1: 47-50

KONRÁDOVÁ, V., KANTA, J., ŠULOVÁ, J. 1990: Effect of bronchoalveolar lavage on the ultrastructure of the tracheal epithelium in rabbits. Respiration 57: 14-20

KONRÁDOVÁ, V., UHLÍK, J., VAJNER, L., ZOCOVÁ, J. 1996: Reaction of the goblet cells to the cholinergic stimulation. Acta Vet. Brno 65: 175-180

KONRÁDOVÁ, V., VAJNER, L., UHLÍK, J., ZOCOVÁ, J. 2000: The effect of Placebo-Inhaler on the tracheal epithelium in rabbits. Vet. Med. - Czech. 45: 189-194

KONRÁDOVÁ, V., VAJNER, L., UHLÍK, J., ZOCOVÁ, J. 2001: Changes in the tracheal epithelium during 24 hours after inhalation of mineral water. Acta Vet. Brno 70: 167-172

LAMB, D., REID, L. 1972: Acidic glycoproteins produced by the mucous cells of the bronchial submucosal glands in the fetus and child: A histochemical study. Brit. J. Dis. Chest 66: 248-253

NEWMAN, T. M., ROBICHAUD, A., ROGERS, D. F. 1996: Microanatomy of secretory granule release from guinea pig tracheal goblet cells. Am. J. Respir. Cell Mol. Biol. 15: 529-539

ROUMAGNAC, I., LABOISSE, C. 1987: A mucus-secreting human colonic epithelial cell line responsive to cholinergic stimulation. Biol. Cell 61: 65-68

SPECIAN, R. D., NEUTRA, M. R. 1980: Mechanism of rapid mucus secretion in goblet cells stimulated by acetylcholine. J. Cell Biol. 85: 626-640

SPECIAN, R. D., OLIVER, M. G. 1991: Functional biology of intestinal goblet cells. Am. J. Physiol. 260: C183C193

STRATMANN, U., LEHMANN, R. R., STEINBACH, T., WESSLING, G. 1991: Effect of sulfur dioxide inhalation on the respiratory tract of the rat. Zbl. Hyg. 192: 324-335

VAJNER, L., UHLÍK, J., KONRÁDOVÁ, V., ZOCOVÁ, J. 2000: The effect of intravenously administered acetylcholine on the glycoconjugate composition in goblet cells of the tracheal epithelium in rabbits. Acta Vet. Brno 69: 17-23

VAJNER, L., KONRÁDOVÁ, V., UHLÍK, J., ZOCOVÁ, J., TŮMA, S. 2001: Vliv intratracheální aplikace iomeprolu na zastoupení glykokonjugátů v sekretu pohárkových buněk epitelu dýchacích cest. Čes. Radiol. 55: 105-108

VAJNER, L., KONRÁDOVÁ, V., UHLÍK, J., ZOCOVÁ, J. 2001: The effect of oral administration of salbutamol on the glycoconjugate composition in goblet cells of the tracheal epithelium in rabbits. Vet. Med.- Czech 46: 65-69

WANNER, A., SALATHÉ, M., O'RIORDAN, T. G. 1996: Mucociliary clearance in the airways. Am. J. Respir. Crit. Care Med. 154: 1868-1902 
Plate III

Konrádová V. et al.: Tracheal... pp. 391-396.

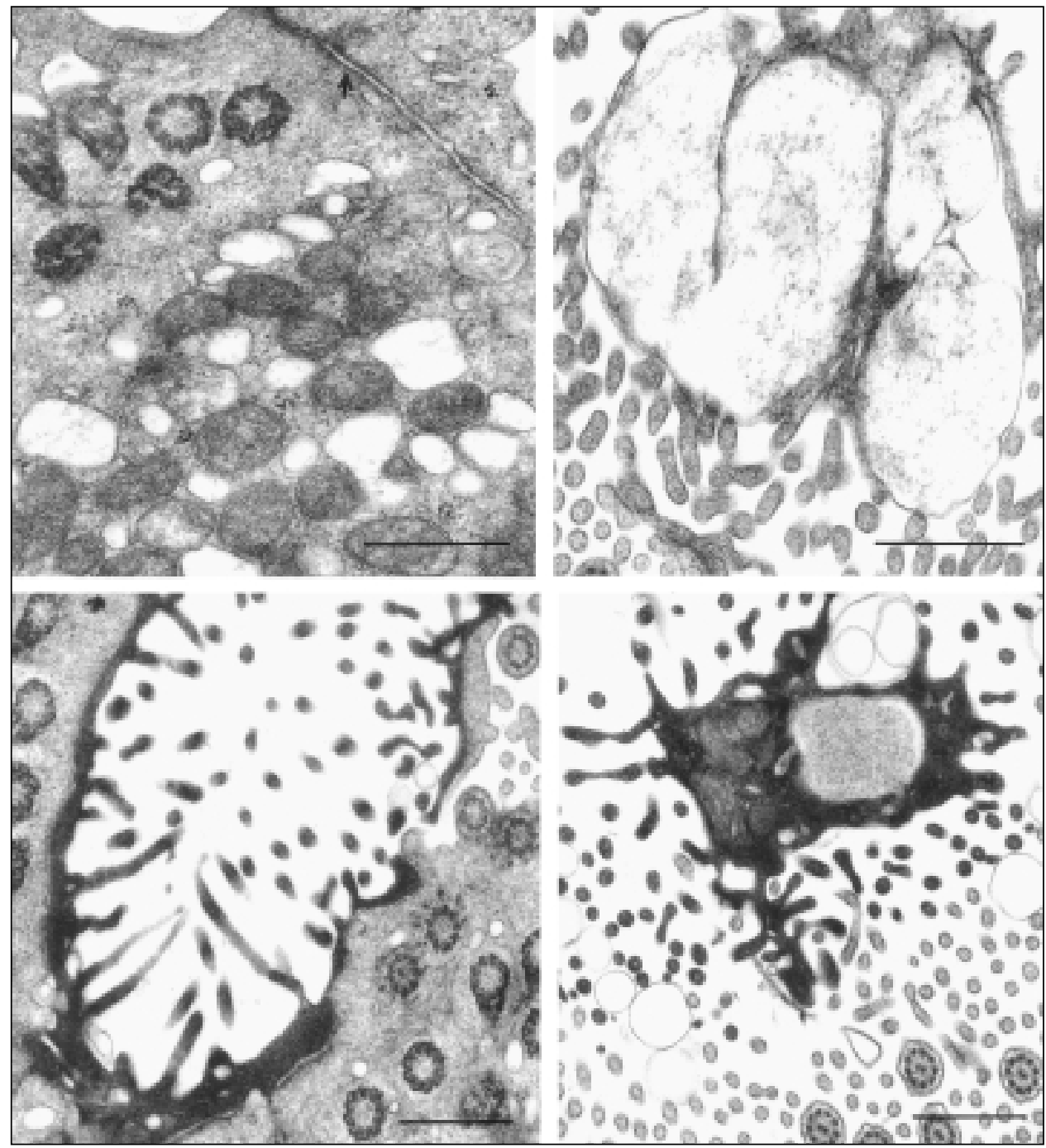

Fig. 3: Intact junctional complex in the apical portion of the epithelium (ヘ). Numerous tiny vacuoles situated in the subcortical portion of the ciliated cell's cytoplasm. Rabbit tracheal epithelium after repeated inhalations of mineral water aerosol. Bar represents $1 \mu \mathrm{m}$.

Fig. 4: Packet of mucous granules separated from a stimulated goblet cell. Rabbit tracheal epithelium after repeated inhalations of mineral water aerosol. Bar represents $1 \mu \mathrm{m}$

Fig. 5: Rim of highly condensed cytoplasm of an exhausted degenerated goblet cell. Rabbit tracheal epithelium after repeated inhalations of mineral water aerosol. Bar represents $1 \mu \mathrm{m}$.

Fig. 6: Portion of cytoplasm of a degenerated sloughed off goblet cell in the area of the ciliary border. Rabbit tracheal epithelium after repeated inhalations of mineral water aerosol. Bar represents $1 \mu \mathrm{m}$. 
Plate IV

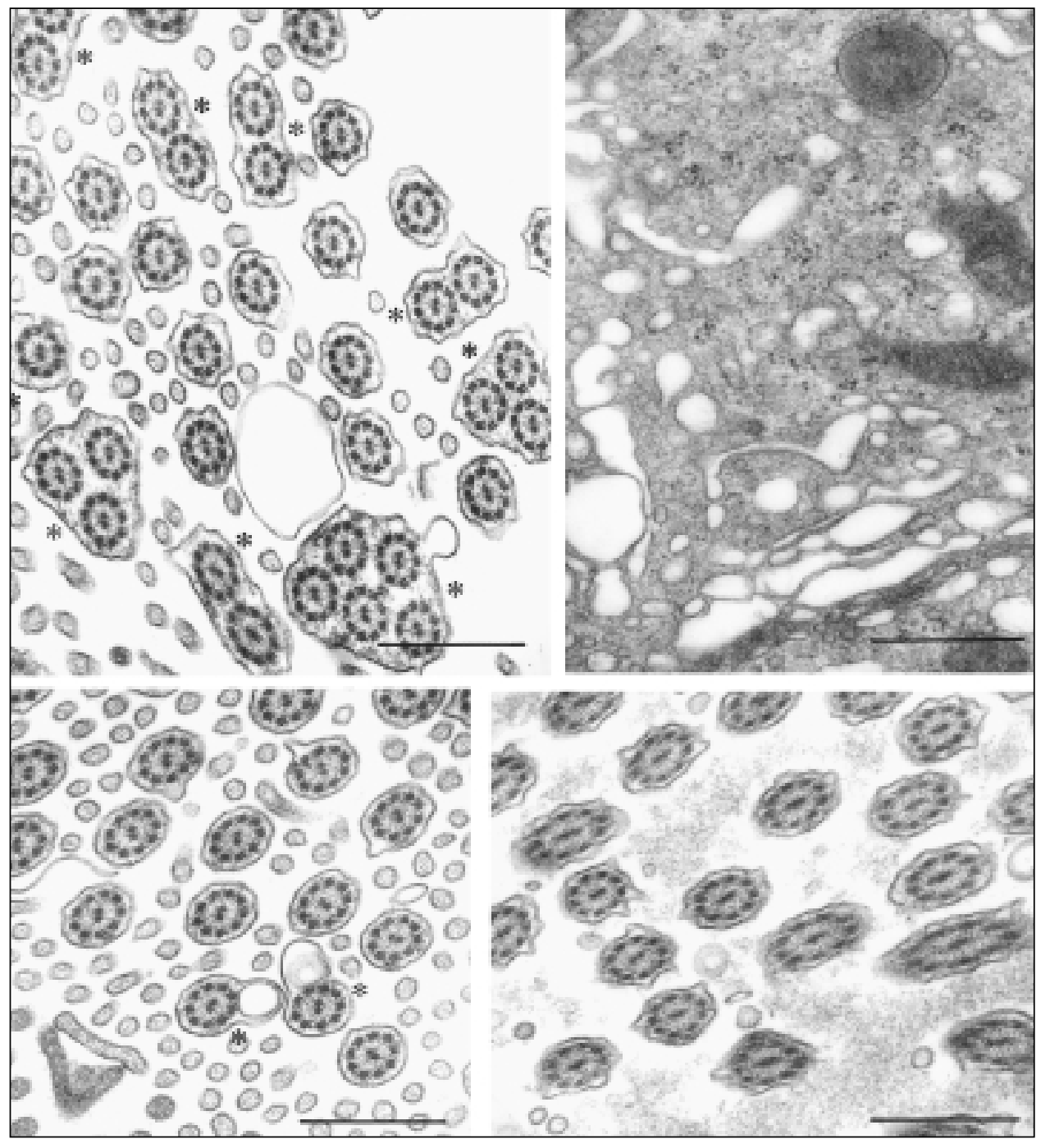

Fig. 7: Small cytoplasmic blebs (*) containing isolated axonemes of degenerating kinocilia in the area of ciliary border. Rabbit tracheal epithelium after repeated inhalations of mineral water aerosol. Bar represents $1 \mu \mathrm{m}$.

Fig. 8: Dilated cisternae of endoplasmic reticulum and of Golgi complex and a small lysosome in the cytoplasm of a slightly altered ciliated cell. Rabbit tracheal epithelium after repeated inhalations of mineral water aerosol. Bar represents $1 \mu \mathrm{m}$.

Fig. 9: Pathological kinocilia containing tiny vacuoles $(*)$ in the area of the ciliary border. Rabbit tracheal epithelium after repeated inhalations of mineral water aerosol. Bar represents $1 \mu \mathrm{m}$.

Fig. 10: Clumps of inspissated mucus among free kinocilia. Rabbit tracheal epithelium after repeated inhalations of mineral water aerosol. Bar represents $1 \mu \mathrm{m}$. 